\title{
TINGKAT KEASINAN DAN UJI ORGANOLEPTIK TELUR AYAM RAS DENGAN WAKTU PERENDAMAN YANG BERBEDA
}

\section{Level of Saltness and Organoleptic on Purebred Eggs with Different Soaking Times}

\author{
Umbang A. Rokhayati ${ }^{1}$ and Soegeng Herijanto ${ }^{2}$ \\ ${ }^{1}$ Department of Animal Husbandry, Faculty of Agriculture, Gorontalo State University \\ ${ }^{2}$ Faculty of Animal Husbandry, Wijayakusuma Purwokerto University \\ Umbang.ung@gmail.com, soegengherijanto@unwiku.ac.id
}

\begin{abstract}
Research on this immersion process aims to determine the organoleptic value and salinity level. The materials used in this study were 90 eggs, rubbing ash and crust salt (table salt). Completely Randomized Design (CRD) was used in this study, by soaking chicken eggs in salt solution for 10, 12 and 15 days.The parameters observed in this study were the organoleptic value and salinity level. The results showed that the duration of soaking eggs in a salt solution had a significant effect on the organoleptic value and salinity of the eggs $(\mathrm{P}<0.05)$ on the organoleptic value and the salinity level of the panelists preferred the results of soaking in a salt water solution with a long soaking time of 12 days.
\end{abstract}

Keywords: organoleptic, salinity level, salted eggs, salt,

\begin{abstract}
ABSTRAK
Tujuan penelitian untuk menganalisis nilai organoleptik dan tingkat keasinan telur yang direndam dalam larutan air garam dengan waktu perendaman yang berbeda. Materi yang digunakan dalam penelitian ini adalah 90 butir telur ayam ras, abu gosok dan garam krasak (garam dapur). Rancangan percobaan yang digunakan adalah Rancangan Acak Lengkap (RAL), dengan merendam telur kedalam alam larutan air garam selama 10, 12 dan 15 hari. Parameter yang diamati pada penelitian ini adalah nilai organoleptik dan tingkat keasinan. Hasil penelitian menunjukkan bahwa lama perendaman telur dalam larutan garam, memberikan pengaruh nyata terhadap nilai organoleptik dan tingkat keasinan telur ayam ras $(\mathrm{P}<0,05)$ pada nilai organoleptik dan tingkat keasinan panelis lebih menyukai telur hasi lperendaman larutan air garam dengan lama perendaman 12 hari.
\end{abstract}

Kata kunci:, Garam, organoleptik, tingkat keasinan, Telur asin

Cara Mengutip (APA Citation Style)

Rokhayati U.A. dan Herijanto S. 2021. Tingkat Keasinan dan Uji Organoleptik Telur Ayam Ras dengan Waktu Perendaman yang berbeda. Jambura Journal of Animal Sciences, 4(1) 41-45 


\section{PENDAHULUAN}

Telur asin merupakan teknologi hasil peternakan yang peminatnya cukup banyak. Sebagian besar telur asin dibuat dari telur bebek. Dimana salah satu pengolahan telur dengan penambahan garam untuk memperpanjang daya simpan telur. Penambahan garam dalam jumlah tertentu mempengaruhi rasa asin pada telur yang diasinkan. Semakin banyak yang dicampurkan semakin panjang juga daya simpannya, namun telur akan semakin terasa asin. Telur mengandung komponen utama yang terdiri dari air, protein, lemak, karbohidrat, vitamin dan mineral. Secara umum, telur terdiri atas tiga komponen pokok, yaitu kulit telur atau cangkang (kira-kira $11 \%$ dari berat total telur), putih telur (kira-kira 57\% dari berat total telur) dan kunin gtelur (kirakira 32\% dari berat total telur) (Suprapti, 2002). Telur asin merupakan telur yang diawetkan dengan cara diasinkan dengan garam $(\mathrm{NaCl})$. Telur asin berkualitas baik memiliki ciri-ciri antara lain memiliki rasa asin yang cukup (pemerama nselama 7-10 hari), memiliki kuning telur yang berwarna kemerah-merahan dan terkesan berpasir atau masir (Suprapti, 2002). Pengasinan merupakan salah satu upaya untuk mengawetkan telur bebek, mengurangi bau amis dan menciptakan rasa khas. Proses pengasinan telur yang umum dilakukan oleh masyarakat dengan menggunakan garam dapur sebagai bahan pengawetnya. Garam merupakan factor utama dalam proses pengasinan telur yang berfungsi sebagai bahan pengawet untuk mencegah pembusukan telur, sehingga meningkatkan daya simpannya (Novia dkk, 2011). Pengasinan telur dapat dilakukan dengan merendam telur dalam larutan garam jenuh (metode basah) dan dengan membalut/membungkus telur dengan adonan garam, dan abu (metode kering) (Lukito, dkk, 2012). Kedua metode pengasinan mempunyai kelebihan masingmasing. Metode basah memiliki kemampuan penetrasi garam kedalam telur berlangsung lebih cepat akan tetapi albumin telur relative lebih basah. Sebaliknya metode kering penetrasi garam lebih lambat dan albumin telur lebih padat. Lukman(2008) mengemukakan bahwa berdasarkan perbedaan metode pengasinan metode kering lebih disukai oleh panelis, sedangkan garam yang digunakan unuk pengasinan masyarakat adalah garam Natrium klorida ( $\mathrm{NaCl} /$ garam dapur) (Puspitasari, dkk, 2014). Penambahan garam pada pengawetan berpengaruh terhadap protein telur. Penambahan garam yang berlebihan dapat berakibat protein mengalami denaturasi. Protein yang adadi dalam telur mengalami denaturasi disebabkan adanya perubahan pada struktur sekunder dan tersier akibat terjadinya interaksi dengan garam (Novia dkk, 2011). Protein yang terdenaturasi berkurang kelarutannya, akibatnya protein akan terpisah sebagai endapan. Denaturasi protein yang dipengaruhi konsentrasi garam berpengaruh pada kadar protein (Winarno, 2008). Tujuan penelitian menganalisis nilai organoleptik dan tingkat keasinan telur yang direndam dalam larutan air garam dengan waktu perendaman yang berbeda.

\section{METODE PENELITIAN}

Penelitian ini telah dilaksanakan selama 1 (dua) bulan mulai sejak JanuariFebruari 2021 diLabolatorium Teknologi Hasil Ternak, Jurusan Peternakan Fakultas Pertanian Universitas Negeri Gorontalo. Metode yang digunakan dalam penelitian adalah percobaan lapangan menggunakan Rancangan Acak Lengkap (RAL) dengan 3 perlakuan, setiap perlakuan menggunakan 30 butir telur ayam ras. Model matematika mengikuti persamaan liner yang disarankan (Lamanta, 2020); (Wahyudi et al., 2020); (Pakaya \& Zainudin, 2019)

$$
Y_{i j}=\mu+\tau_{i}+\epsilon_{i j}
$$

Keterangan:

$Y_{i j}=$ Pengamatan perlakuan ke-i dan ulangan ke-j

$u=$ Rataan pengamatan

$\tau_{i}=$ efek perlakuan ke-i $(\mathrm{i}=1,2,3,4,5)$

$\epsilon_{i j}=$ efek galat perlakuan ke-i dan ulangan ke-j $(j=1,2,3,4)$ 
Perlakuan yang digunakan dalam penelitian yaitu :

P1 = Direndam dalam larutan air garam selama 10 hari

P2 = Direndam dalam larutan air garam selama 12 hari

P3 = Direndam dalam larutan air garam selama 15 hari

\section{Prosedur Penelitian}

a. Menimbang dan menyeleksi telur untuk mendapatkan keseragaman. Mengamplas permukaan telur dengan kertas pasir berukuran 400-600.

b. Menyiap kanwadah dan membuat larutan air garam dengan perbandingan 500gr garam laut dan 2 liter air bersih.

c. Memasukan telur yang sudah di amplas ke dalam wadah sesuai dengan kode perlakuan.

d. Setelah 10 hari, 12 hari dan 15 hari, masing-masing telur perlakuan diambil, direbus dan dinilai oleh panelis terlatih untuk menentukan skor organoleptik dan tingkat keasinan.

Variable yang diamati dalam penelitian ini adalah nilai organoleptik dan tingkat keasinan telur. Sampel dinilai dan dianalisis oleh panelis terlatih sebanyak 10 orang.

\section{Analisis Data}

Data yang diperoleh dianalisis dengan analysis of variance berdasarkan rancangan acak lengkap (RAL)

\section{HASIL DAN PEMBAHASAN}

Hasil penelitian menunjukan bahwa perbedaan waktu perendaman telur berpengaruh terhadap organoleptik dan tingkat keasinan telur. Nilai rata-rata organoleptik dan tingkat keasinan telurhasil perendaman dapat dilihat pada Tabel 1.

Tabel 1. Nilai rataan organoleptik dan tingkat keasinan telur hasil perendaman

\begin{tabular}{ccc}
\hline Perlakuan & Organoleptik & Tingkat Keasinan \\
\hline P1 (10 hari perendaman) & $2,1 \mathrm{~b}$ & $1,6 \mathrm{a}$ \\
P2 (12 hari perendaman) & $3,7 \mathrm{c}$ & $2,7 \mathrm{~b}$ \\
P3 (15 hari perendaman) & $1,3 \mathrm{a}$ & $4,6 \mathrm{c}$ \\
\hline
\end{tabular}

Perbedaan angka menunjukan perbedaan yang signifikan $(\mathrm{P}<0,05)$

Organoleptik: $\quad 1$ = Sangat tidak suka. 2 = Tidaksuka. $3=$ Netral. $4=$ Suka. $5=$ Sangat suka

Keasinan: $\quad 1$ =Sangat tidak asin. 2 = Tida kasin. $3=$ Kurang Asin. $4=$ Asin. $5=$ Sangat Asin

\section{Hasil Uji Organoleptik}

Berdasarkan hasil analisis statistic menggunakanan alisis sidik ragam menunjukkan bahwa telur ayam ras yang direndam dalam larutan air garam dengan waktu simpan yang berbeda memberikan pengaruh nyata terhadap nilai organoletik telur tersebut $(\mathrm{P}<0,05)$. Berdasarkan hasil analisis tersebut panelis lebih menyukai telur ayam ras hasil perendaman dengan masa simpan 12 hari dengan nilai 3,7 (antara netral dan suka). Hasil penelitian menunjukan bahwa semakin tinggi konsentrasi garam dalam air untuk merendam telur maka semakin tinggi pula tingkat keasinan telur dan tingkat keasinan tersebut mempengaruhi tekstur dari kuning telur. Kuning telur yang mendapatkan skor nilai keasinan tertinggi menghasilkan kuning telur yang masir (berbutir- butir seper tipasir) hal inilah yang membuat nilai organoleptik telur menjadi berbeda. Hasil ini sesuai dengan pendapat Oktaviani $d k k$ (2012) menyatakan bahwa warna kuning telur sebelum mengalami proses pengasinan adalah kuning, warna akan berubah menjadi kuning kecoklatan, cokelat tua, orange atau kuning cerah setelah melalui proses pengasinan. Dengan demikian pengasinan menyebabkan kadar air telur menurun sehingga warna orange pada kuning telur semakin pekat. Kadar air mempengaruhi konsentrasi pigmen, sedangkan lemak bebas mempengaruhi keluarnya pigmen. Kuning telur merupakan suatu emulsi lemak dalam air dengan kandungan bahan kering sekitar $50 \%$ yang terdiridari $2 / 3$ lemak dan $1 / 3$ protein.

\section{Tingkat Keasinan}

Berdasarkan hasil analisis sidik ragam telur hasil perendaman dengan 
larutan air garam dan setelah diuji oleh panelis terlatih, perbedaan waktu perendaman telur memberikan pengaruh yang nyata terhadap tingkat keasinan $(\mathrm{P}<0,05)$, berdasarkan uji lanjut Duncan panelis lebih dominan menyukai telur dengan masa perendaman 12 hari dengan mendapat skor 2,7 dibandingkan dengan telur pada P1 (10 hari perendaman) dengan skor 1,6 dan P3 (15 hari perendaman) dengan skor 4,6 . Semakin tinggi skor dari panelis menunjukan bahwa semakin tinggi pula tingkat keasinan telur hasil perendaman. Perbedaan tingkat keasinan disebabkan lamanya perendaman maka semakin tinggi pula tingkat keasinan, hal ini disebabkan oleh kadar $\mathrm{NaCl}$ dalam air yang masuk kerongga-rongga telur mentah yang sebelumnya diamplas dan semakin lama telur direndam maka semakin besar pula $\mathrm{NaCl}$ yang mampu mengiikat air sehingga telur terasa semakin asin seiring dengan lamanya waktu perendaman. Menurut Sultoni (2004), bahwa karakteristik tingkat keasinan telur asin sangat dipengaruhi oleh kadar air dan kadar garam dari telur sehingga nantinya dapat berpengaruh terhadap tingkat kesukaan.

\section{DAFTAR PUSTAKA}

Lamanta, I. L. (2020). PEMANFAATAN AKAR ECENG GONDOK (EOCORNIA CRASSIPES) SEBAGAI BAHAN PENGAWET TELUR AYAM RAS. Jambura Journal of Animal Science, 3(1), 46-53. https://doi.org/10.35900/jjas.v3i1.271 1

Lukito, G. A., Suwarastuti, A., \& Hintono, A. (2012). Pengaruh berbagai metode pengasinan terhadap kadar $\mathrm{NaCl}$, kekenyalan dan tingkat kesukaan konsumen pada telur puyuh asin. Animal Agriculture Journal, 1(1), 829838.

Lukman, H. 2008. Pengaruh Metode Pengasinan dan Konsentrasi Sodium Nitrit Terhadap Karakteristik TelurItik Asin. Jurnal Ilmiah Ilmu Peternakan, XI (1): 9-17.
Hal ini sejalan dengan pendapat Nurhidayat $d k k$ (2013) yang menyatakan bahwa Kemasiran telur asin dapat terjadi karena kemampuan $\mathrm{NaCl}$ untuk mengikat air mempunyai afinitas yang lebih besar dari pada protein menyebabkan ikatan antar molekul semakin kuat. Ikatan yang kuat menyebabkan protein menggumpal. Pengumpalan protein dalam kuning telur menyebabkan rasa asin dan berpasir serta Rasa masir dari kuning telur juga dipengaruhi oleh besaran minyak yang keluar, kekuatan gel dari kuning telur dan diameter granula kuning telur. Semakin tinggi nilai ketiga criteria mutu tersebut, rasa masir kuning telur dihasilkan semakin tinggi (Novia $d k k, 2011$ ).

\section{KESIMPULAN}

Berdasarkan hasil dan pembahasan maka dapat di simpulkan bahwa perbedaan waktu perendaman telur dalam larutan air garam dapat mempengaruhi nilai organoleptik dan tingkat keasinan telur. Telur dengan lama perendaman 12 hari memberikan hasil terbaik berdasarkan penilaian panelis baik nilai organoleptik maupun tingkat keasinan.

Novia, D., S. Melia dan N. Z. Ayuza. 2011. Kajian Suhu Pengovenan Terhadap Kadar Protein dan Nilai OrganoleptikTelur Asin. JurnalPeternakan, 8 (2): 70-76

Nurhidayat, Y., J. Sumarmono dan S. Wasito. 2012. Kadar Air, Kemasiran Dan TeksturTelur Asin AyamNiaga yang Dimasak dengan Cara Berbeda. Jurnal Ilmiah Peternakan, 1(3): 813-820.

Oktaviani, H., N. Kaniada dan N. R. Utami. 2012. Pengaruh Pengasinan Terhadap Kandungan Zat Gizi Telur Bebek Yang Diberi Limbah Udang. Jurnal Unnes of life Sciense, 1(2): 106-112.

Pakaya, S. A., \& Zainudin, S. (2019). PERFORMA AYAM KAMPUNG SUPER YANG DI BERI LEVEL PENAMBAHAN TEPUNG KULIT KAKAO (Theobroma cacao, L.) 
FERMENTASI DALAM RANSUM. Jambura Journal of Animal Science, 1(2). https://doi.org/10.35900/jjas.v1i2.260 3

Puspitasari, C., D. Rachmawanti dan Siswanti. 2014. Pengaruh Kombinasi Media dan Konsentrasi Iodium Pada Dua Jenis Garam (Nacl Dan Kcl) Terhadap Kadar Iodium dan Kualitas Sensoris Telur Asin.JurnalTeknosains Panga, 3 (4): 1-7.

Sultoni A. 2004. Pengaruh konsentrasi larutan asam asetat dan lama perendaman terhadap beberapa karakteristik telura sin dari telur itik
Jawa (Anas javanicus). (Skripsi). Fakultas Pertanian Universitas Padjadjaran, Jatinangor.

Suprapti, L. M. 2002. PengawetanTelur. Kanisius, Yogyakarta.

Wahyudi, F., Datau, F., \& Dako, S. (2020). KARATERISTIK FESES AYAM KAMPUNG SUPER YANG DIBERI KUNYIT. Jambura Journal of Animal Science, 3(1), 31-37. https://doi.org/10.35900/jjas.v3i1.732 6

Winarno, F. G. 2008. Kimia Pangan dan Gizi. Jakarta: PT Gramedia Pustaka Utama. 